\title{
Public Library Adult Education for Immigrants in North Carolina
}

$\mathrm{I}$ $\mathrm{n}$ the period from 1876, the founding year of the American Library Association, to 1924 , the effective year of the National Origins Act with its quotas for immigrants, U.S. public libraries of the Northeast, the West, and the Midwest were busy organizing to serve the needs of the flood of millions of immigrants from Southeastern and Central Europe, Russia, and the Middle East. ${ }^{1}$ North Carolina did not receive any significant number of immigrants from this influx as they had earlier immigrants, including Germans, English, French, Irish, and Scots, from the seventeenth, eighteenth, and nineteenth centuries. By 1880, these former immigrants were now established North Carolina citizens who had been assimilated, or Americanized, the term used in the early twentieth century, and spoke English, albeit in differing and sometimes colorful accents and dialects.

The majority of immigrants came into the U.S. through the major port of New York. Many immigrants stayed there while others went on to Chicago and throughout the Midwest. During World War I, the American Library Association (ALA) was successful in providing books to foreign- and nativeborn soldiers and sailors, due to a generous grant of $\$ 320,000$ from the Carnegie Corporation of New York, which funded the ALA War Service Committee $^{2}$ North Carolina did not benefit directly from this grant and subsequent ones for serving newly arrived immigrants since there were at that time no sizable immigrant communities needing Americanization services to help them adapt to life in a new country and North Carolina public libraries were in the early stages of development.

\section{ALA Committee on Work with the Foreign Born}

As part of the renewed interest in continuing library services to the foreign born after World War I, the ALA Committee on Work with the Foreign Born (CWFB) was established in February 1918, the first ALA organization charged exclusively to serve immigrants as a clearly defined population. The ALA CWFB's explicit mission was straightforward: "to collect from libraries and to supply to them information on desirable methods of assisting in the education of the foreign born, in American ideals and customs and the English language." 3 The implicit mission, however, which was adhered to by many librarians, social workers, immigrants' rights advocates, and other Progressive Era reformers was to provide Americanization services without force or coercion, without the mandate for immediate conformity, and within a framework of cultural pluralism, a new sociological construct introduced by Horace M. Kallen. ${ }^{4}$

The ALA Executive Board appointed as the ALA CWFB's first chair, John Foster Carr, an ALA employee as well as Founder, Director, and sole employee of his Immigrant Publication Society of New York. Carr had been active in the ALA book drive for soldiers and sailors during World War I, and during the decade prior to his appointment, he had written a series of
Guides to the United States for immigrant groups, including an English edition as well as versions for Italian, Jewish (Yiddish), and Polish immigrants, which he distributed on a subscription basis to libraries, patriotic societies, and social work agencies through his Immigrant Publication Society. ${ }^{5}$

\section{ALA Enlarged Program}

Carr, concurrently as chair of the ALA CWFB, was given the responsibility for the financial management of a proposed new campaign to expand library services not only to immigrants, but also to other unserved or underserved populations: the ALA Enlarged Program. The ALA leadership projected that two million dollars would be needed for implementing the Enlarged Program to include library extension or outreach services, work with the foreign born, adult self-education, work with the blind, and institutional library development. Rather than being embraced by the majority of ALA members, however, the Enlarged Program threatened to tear apart a still fledgling organization. Many librarians objected that, while they supported the public library's role in scholarship, they had not accepted that the ALA had a role to play in adult self-education, a new untested concept. Other librarians questioned the ALA's provision of services directly to readers, implying that this smacked of welfare rather than professionalism. The library community was simply not ready to engage in yet another fund-raising campaign without the slightest hope 
of matching the success of the ALA War Service. Action on the Enlarged Program became hopelessly deadlocked. The ALA Executive Board, chaired by Carl H. Milam, was forced to close the fund-raising campaign in December $1920 .^{6}$

Carr, who had in the meantime served as chair of the ALA CWFB for two terms, was relieved of his position with the ALA after December 1920, his reputation tainted by his association with the widely criticized ALA Enlarged Program and his failure to raise anywhere near the two-million-dollar goal. In his defense, Carr was the catalyst to get the ALA leadership to reexamine its mission "to provide the best reading for the most at the least cost," in light of the thousands of immigrants, who, at this critical point in their lives, dreamed of becoming citizens of the U.S. and sought help from any organization that would help them reach that goal. Two very capable leaders emerged to carry forth the work of the ALA CWFB from 1918 to 1948: Eleanor Edwards Ledbetter, librarian of the Broadway Branch in Cleveland, and Edna Phillips, of the Massachusetts Free Public Library Commission and, later, the Morrill Memorial Library of Norwood, Massachusetts. The work of the ALA CWFB was almost exclusively with European immigrants because of immigration laws forbidding or limiting immigration from Asia. $^{7}$

The disappointing failure of the Enlarged Program brought about a conservative wait-and-see policy to an already conservative ALA during the early 1920s and, as a counterbalance, the beginning of a less hysterical reexamination of what had gone wrong. ALA leaders found it difficult to abandon their conservative attitudes and purported that to do anything would jeopardize their expressed neutrality on political and social issues.
However, there were in ALA's existing programs a variety of library services for adults already being delivered by public libraries that promised to be popular, helpful, and non-confrontational. These core services included reading guidance (known as readers' advisory service); services for special groups, notably immigrants, but also youth and adults with little or no education; departmentalization of libraries based on subject; and services in collaboration with community groups. With World War I not yet a distant memory, library sponsorship of educational programs to promote democratic values in an increasingly pluralistic society assumed more urgency. ${ }^{8}$

\section{Carnegie Corporation of New York and the Adult Education Movement}

The ALA turned once again to the Carnegie Corporation of New York for funding of the adult self-education component of the failed ALA Enlarged Program. The Carnegie Corporation's support of libraries, particularly constructing them, was well known. The Corporation, like the ALA itself, was from its beginning in 1911 influenced by conservative leaders, including its early presidents, Elihu Root, James Angell, Henry Pritchett, and Frederick Keppel. It was under the progressive leadership of Frederick Keppel that the Corporation officially recognized the public library as a major agency for adult education. ${ }^{9}$

In 1918, the Corporation funded a two-year study on Americanization and its effects on the assimilation of immigrants in the areas of immigrant education, immigrant heritages, immigrant press, immigrants in rural areas, health standards and care of immigrants, home and family life, the naturalization process and other political issues for immigrants, legal protection, and industrial and economic opportunities. Each area was addressed by an expert. John Daniels, the expert responsible for community-based organizations involved in the Americanization process, scrutinized the activities of public libraries and was convinced that the public library was the ideal institution for the Americanization of the immigrant community. His study, titled America Via the Neighborhood, was published in 1920 by Harper Brothers. It projected a progressive attitude toward immigration, naturalization, and Americanization, and praised the work of Jane Maud Campbell of the Passaic (NJ) Public Library, and later the Massachusetts Free Public Library Commission. ${ }^{10}$

In 1924, William Learned, an associate of the Corporation, demonstrated his agreement with president Keppel about the potential of the public library as an agency for adult education in his report to the Corporation titled The American Public Library and the Diffusion of Knowledge. Endorsed by Keppel for distribution to a wider audience, the so-called Learned report included a summary of significant adult library services already developed and implemented in public libraries, including subject departments in the Cleveland Public Library; reading courses available for purchase in the Chicago Public Library; the ALA Reading Courses series; and the U.S. Bureau of Education reading courses series. According to Learned, the report represented a philosophical framework, not only for adult education per se, but also for the diffusion of ideas and general knowledge to the general public. It is clear that the Corporation considered services to immigrants an integral part of library adult education, and through its funding of the ALA endowment, the Corporation indirectly continued the funding for the ALA CWFB. ${ }^{11}$ 
In January 1924, the ALA Bulletin's editorial column announced a general ALA membership session on library adult education at the upcoming ALA annual conference that summer in Saratoga Springs, New York. Judson T. Jennings, librarian of the Seattle Public Library, and then ALA President, addressed the membership. Jennings endorsed public librarianship's interest in adult education, and identified three short-term objectives for
$\$ 24,500$ for this study and formed an advisory committee, which included John Cotton Dana of the Newark Public Library, known for his sharp criticism of the concept of adult education, along with Carl H. Milam, ALA Executive Director, as official representatives of the ALA. Together, representatives from the library and adult education communities took steps in the formation of what would become, in 1926, the American Association for

\section{${ }^{6} \mathbf{C i b r a r y}_{\text {adult education specialists gave priority to }}$ community leadership program planning, counseling on library resources, the use of library materials in library- sponsored programs, and library staff training."}

the ALA: training competent personnel; extending library service to all areas of the country, notably rural areas; and participating in the developing national adult education movement. Jennings recommended that every large public library employ readers' advisers for reading guidance; develop reading courses, particularly for out-of-school youth; and encourage the publishing of readable and interesting books to be provided in quantities at low cost, an allusion both to Melvil Dewey's motto for the ALA, and to the Carnegie Corporation's mission of diffusing knowledge and ideas to the greatest number. ${ }^{12}$

\section{Library Adult Education Movement}

Reaction to ALA President Jennings's speech was generally enthusiastic. Jennings was appointed chairman of the ALA Commission of the Library and Adult Education in 1924 and instructed to conduct a two-year study of libraries and their potential for promoting adult education. In 1925, the Carnegie Corporation granted the ALA
Adult Education (AAAE), a subsidiary and funding arm which would work in tandem with the Corporation to advocate and partially fund the growing interest in adult education through

In 1926, the ALA Commission's report, Libraries and Adult Education, recommended that public libraries organize adult education departments and programs adapted to the needs of special groups, including immigrants, workers, unions, university extension students, public school youth, the blind, and inmates of hospitals and prisons. Librarians began to look to the readers' advisers and specialist librarians, who had adapted traditional services to the needs of special groups in the community, as the appropriate leaders for library adult education.

Also, in March 1926, the ALA Commission became the ALA Board on the Library and Adult Education. With the consensus of library community opinion being that the reader's advisory service should be the principal focus of adult education, the American public library community had a clearer public libraries. vision of its role as an agency of library adult education. Critics like Dana warned of the overreliance on the readers' adviser's role in light of the library's role and reminded the membership of the ALA's stance on political neutrality in a pluralistic democratic society. ${ }^{13}$

\section{ALA Survey of Libraries in the United States}

Using Carnegie Corporation funds from 1926 to 1927, the ALA designed and administered a survey of U.S. academic, public, and school libraries to document general library resources and services offered in libraries throughout the nation as well as specific resources and services offered for immigrants since 1876, the founding year of the ALA.

The section of the Survey related specifically to public library adult education with immigrants was based on responses received from less than forty libraries in five basic areas of library administration:

1. book selection

2. cooperation with other American social and educational agencies

3. cooperation with parochial and public schools and foreign social organizations

4. work with adult education classes, both day and evening programs

5. library publicity

The section on book selection included statistics from twenty-eight cities, representing the major census divisions of the country, but including mainly cities in the Northeast and Midwest states. The thirty-three languages represented, with the exception of limited Japanese holdings in the public libraries of Los Angeles and Portland (OR), were classified as IndoEuropean.

The public libraries of five cities and the District of Columbia represented the South Atlantic states in the Survey, 
including Atlanta at 2\%; Baltimore at $12 \%$; Norfolk at 6\%; Richmond at 3\%; Washington, D.C. at 7\%; and Wilmington, Delaware at $15 \%$. North Carolina public libraries mentioned in the Survey were the Carnegie libraries of Durham, Greensboro, and WinstonSalem, but no statistics of foreignlanguage holdings were provided. The Survey did mention the University of North Carolina (UNC), the North Carolina College for Women (now UNC-Greensboro), Duke University, and Greensboro College, but their holdings would not have been available to the general immigrant population and no specifics about their collections were provided. ${ }^{14}$ From the late 1920 s to the early 1950s, there were no reports in the general library periodical press about services to immigrants in North Carolina.

\section{Fund for Adult Education (FAE) of the Ford Foundation}

The figures in the Survey soon became outdated in light of significant library developments throughout the country. It was not until the early 1950s when the ALA Survey of Adult Education Activities, financed by a $\$ 34,700$ grant from the Fund for Adult Education (FAE), a subsidiary and funding arm of the Ford Foundation, was conducted in 1952 and 1953 by Helen Lyman Smith, and published by the ALA in 1954 as Adult Education Activities in Public Libraries.

Her report, which dealt extensively with group library services for adults, demonstrated the differences in opinion among librarians and library adult education specialists. Librarians in general gave priority to publicity, including exhibits, lectures, and book talks. Library adult education specialists gave priority to community leadership program planning, counseling on library resources, the use of library materials in library-sponsored programs, and library staff training.

The Smith survey documented that of the 1,692 public libraries responding, only 364 conducted studies of community needs and resources. Of the remaining 1,328 , which did not engage in surveying their respective communities to determine local needs, only 146 expressed any interest. Of the libraries surveyed, only $9 \%$ offered adult library services with immigrants or, more specifically, the foreign born, the term used in the report. Respondents were in the main from libraries of the Northeastern, Midwestern, and Western states. ${ }^{15}$

\section{ALA Library-Community Project and the Cumberland County Library}

In 1955, renewed interest in library adult education was promoted by an FAE grant in the amount of $\$ 200,000$ to fund the ALA Library-Community Project. The Library-Community Project, which continued until 1960 under the direction of Ruth Warncke of the ALA, was implemented to follow up on the distressing finding in the Smith survey that many libraries had no (emphasis added) interest in surveying their communities to determine what adult services were needed to fulfill their needs. It was assumed that, if these initially uninterested libraries were given help from qualified adult education consultants, they would have responded more positively.

The FAE grant provided funds for consultants to help pilot libraries undertake community surveys of their users. The pilot libraries in the LibraryCommunity Project were the Ottawa (KS) Public Library, the Wicomico (MD) County Library, the ClinchPowell (TN) Regional Library, the Hackley Public Library (Muskegon, $\mathrm{MI}$ ), the Hastings (NE) Public Library, the Shawano (WI) City-County
Library, the Ardmore (OK) Public Libraries, and the Cumberland County (NC) Public Library. ${ }^{16}$ North Carolina was from this point onward part of the professional discourse about public library services with immigrants.

The Cumberland County Public Library, which reported a collection of approximately 2,000 foreign-language materials in its application, requested consultants to help determine how these materials could be used in Cumberland County, the home of Fort Bragg, and perhaps throughout North Carolina. The fact that Fort Bragg was under the control of the federal government, funds were more readily available to the surrounding Cumberland County and the city of Fayetteville when the Civil Rights Era reforms began in North Carolina. It was not until the Civil Rights Era, during the 1960s and culminating in 1965 with federal legislation, that North Carolina's public libraries were integrated, an unfortunate situation that held back North Carolina public libraries' development as a statewide resource.

\section{North Carolina Foreign Language Center (NCFLC)}

The NCFLC was established in 1976 by the State Library of North Carolina through a Library Services and Construction Act (LSCA) grant of $\$ 88,000$. The Cumberland County Public Library \& Information Center (CCPL\&IC) was chosen as the site for the new North Carolina Foreign Language Center (NCFLC) due to Cumberland County, North Carolina's large non-English-speaking population, including immigrants from Southeast Asia, and its acquisitions of foreignlanguage materials. For twenty-two years, the library would be the recipient of federal funds in the form of continuing LSCA grants to develop a foreign-language collection for the use of the state of North Carolina. ${ }^{17}$ 
Four years after the establishment of the NCFLC, in the fall of 1980 , Library Trends published a survey of library services to non-English-language ethnic minorities in the U.S. taken by Natalia B. Bezugloff, Head of the Foreign Literature Department of the Cleveland Public Library. She contacted 127 public libraries offering multilingual library services in all 50 states, including North Carolina. Of the 102 responses she received, 72 had foreign-language collections of various sizes in more than 70 foreign languages.

Of the 45 libraries that reported the age of their collections, 10 were started before 1900, 13 in the early 1900 s before World War I, and 22 since World War I. These 45 libraries provided a variety of services to the ethnic communities they served, including readers' advisory service, and routine visits to and materials for English as a Second Language (ESL) and citizenship classes. The most positive outcome reported in her study was a marked increase in use of foreign-language and language-learning materials by secondand third-generation descendants of immigrants, a finding that demonstrated the continuing need for multicultural adult library services. ${ }^{18}$

In 1990, the ALA RASD Services to Adults Committee's announced the completion of its survey of adult education programs in U.S. public libraries. The survey, begun earlier in 1983 as the Adult Services in the Eighties (ASE) project, represented an expansive update of Helen Lyman Smith's 1954 survey.

An analysis of the survey, edited by Kathleen M. Heim (now de la Pena McCook) and Danny P. Wallace, was published by the ALA in 1990 as Adult Services: An Enduring Focus for Public Libraries. The results of the survey documented increases in and improvements to services with immigrants and minorities since the Smith survey. The questionnaire was distributed to 1,758 library systems, representing more than 8,000 single-unit libraries, central libraries, and branches. Responses were received from 4,215 individual libraries representing 1,114 systems. Results showed that public libraries had organized 18 programs based on the needs participating libraries. As of fiscal year 2007, the State Library of North Carolina had provided partial support for the NCFLC with year-to-year federal funds to supplement the fees generated by the subscription service.

The State Library of North Carolina resumed support for the NCFLC for fiscal year (FY) 2007-08 with a

\section{$\mathbf{6}$ It is clear from the evidence available that North Carolina is accepting the challenges attendant to being an immigrant-receiving state. 9}

of ethnic and minority groups. States that offered 10 or more programs either for specific minorities or based on minority concerns in general included California, with 66; New York and Illinois, with 27 each; Texas, with 26; and Massachusetts, with 11 . Only 504 libraries out of the 4,215 responding, a little less than 12 percent, reported programming aimed at advocacy for multiculturalism and the human rights of minority clienteles. ${ }^{19}$

After 22 years of service to the state, the North Carolina Foreign Language Center had grown in staff and services. Ironically, however, fiscal year 1998-99, when the NCFLC had six full-time staff members and a budget of $\$ 253,914$, would be the last year the NCFLC operated under the full support of Library Services \& Technology Act (LSTA) grants, the LSTA having replaced the LSCA. After debates outlining the pros and cons, the State Library of North Carolina discontinued support for the NCFLC in June 1998. As a result, in July 1998, the CCPL\&IC developed an alternative program to continue this service: a fee-based subscription service to North Carolina libraries to provide deposit collections and interlibrary loan services on a sliding scale to
$\$ 45,000$ budget. For FY 2008-9, the State Library awarded the NCFLC an LSTA grant totaling $\$ 153,764$, with $\$ 133,364$ designated to be spent on new materials to refresh the foreignlanguage collection. The State Library continued to subsidize NCFLC operations with LSTA grants for FYs 2009-10 and 2010-11.

\section{CCPL\&IC Foreign Language Collection}

By mutual agreement, the CCPL\&IC and the State Library made a bilateral decision to discontinue NCFLC operations at the end of FY 2010-11 due to falling number of subscriber libraries. The headquarters manager and staff were charged with reviewing the foreign-language collections to make decisions on which languages to retain, based on usage by CCPL\&IC customers, since the bilateral decision was made for the NCFLC to continue to make NCFLC materials available to North Carolina public libraries through interlibrary loan. From this point onward, the NCFLC materials began to be referred to simply as the Foreign Language Collection (FLC). As a result of a review of user requests for foreign language materials after the end of NCFLC operations in 2011, the 
CCPL\&IS reduced the number of core languages over about two years.

As of 2014, the CCPL\&IC headquarters library had 9,857 adult and juvenile books in Spanish, Chinese, Japanese, and Korean, and a small budget of about $\$ 5,000$ to maintain the collection of contemporary novels, poetry, standard classics, popular nonfiction, and children's books in these four core languages. The department's staff creates book bundles of books and other materials in these languages for checkout to CCPL\&IC customers and through interlibrary loan. The FLC continues to offer via interlibrary loan the folk and traditional music recordings left over from the original LSTAsponsored NCFLC collection. ${ }^{20}$

\section{North Carolina Public Library Use by Immigrants in the Twenty-first Century}

Frances Flythe's 2001 master's thesis was based on her interviews with seventy-one Hispanic immigrants in Durham County, North Carolina. She found that $22 \%$ had used the library at some time. In general she, along with most researchers in this area, found that barriers to public library use by Latino immigrants included cultural unfamiliarity with libraries, language barriers due partially to low education and literacy levels, and an overall mistrust of government agencies. Similar findings were reported in 2000 by John Sudell in his chapter on "Library Service to Hispanic Immigrants of Forsyth County, North Carolina: A Community Collaboration," which appeared in Library Services to Latinos: An Anthology. He also reported that Latinos found barriers to library use in scheduling conflicts and location-related issues. ${ }^{21}$

Susan K. Burke in her 2009 survey of the use of public libraries by immigrants gave the findings of several studies based in North Carolina. ${ }^{22}$ She reports that in 2000, the State Library of North Carolina commissioned Rincon and Associates to produce a study on the library needs of Hispanics living in North Carolina. Based on 1,003 telephone interviews, they found that $26 \%$ of Hispanic respondents had used the public library at least monthly, with $40 \%$ reporting use in the past year. The study indicated that the most influential factors in library use were the respondent's belief that he or she lived close to a library, those who rated Englishreading skills and higher education more highly, and those with children under eighteen years of age.

\section{The Challenge Ahead for Public Libraries Serving Immigrants}

Approximately one million immigrants come to the United States per year. In 2010, North Carolina at 7.5\% ranked $23^{\text {rd }}$ out of the 50 states and the District of Columbia. The growth in the immigrant population in North Carolina was more than twice the national average of $28 \%$ percent over the last decade, with North Carolina at $67.2 \%$ in 2010 . In just two years, as of 2012, North Carolina's share of immigrant population was $7.7 \%$ or 748,072. ${ }^{22}$

A Center for Immigration Studies (CIS) report, titled appropriately Immigrants in the United States: A Profile of America's Foreign-Born Population, was published in 2012 and included statistics through 2010. Steven A. Camarota, CIS Director of Research, provided cogent statistics that should drive planning efforts for the improvement of public library adult education services to immigrants in North Carolina, including

- Places of birth of immigrants in North Carolina are Africa (6.2\%), Asia (23.9\%), Europe (11.0\%), Latin America (includes South America,
Central America, Mexico, and the Caribbean) (56.3\%), North America (Canada, Bermuda, Greenland, and St. Pierre and Miquelon) (2.1\%) and Oceania (0.5\%).

- A near majority of Spanish-speaking immigrants from Guatemala,

Honduras, Mexico, El Salvador and the Dominican Republic report that they speak English not at all or not well. There is a large body of research showing that language skills are a key determining factor for immigrant earnings.

- Native-born Hispanics are significantly better off than immigrant Hispanics, but still lag well behind non-Hispanic natives, even by the third generation.

- An analysis of occupations showed that the vast majority of workers in almost every job were U.S.-born, including three fourths of janitors and two-thirds of construction laborers and meat processors. The share of immigrant men holding a job is higher than that of native-born men.

- Illegal immigrants and their U.S.born children as a share of the school-age population (ages 5-17) in North Carolina were $1 \%$ or 25,000 .

- In North Carolina, $35.7 \%$ of the immigrant population had less than a high school education, while for natives it was $8.2 \%$.

- The top 10 Non-English languages spoken in NC are Spanish, Hindi and related Indian languages, French, Chinese, German, Vietnamese, Arabic, Dravidian, Korean, and Sub-Saharan African languages. ${ }^{23}$ It is clear from the evidence available that North Carolina is accepting the challenges attendant to being an immigrant-receiving state. North Carolina public libraries no longer have the time to debate whether or not to serve the already established immigrant communities in North Carolina as well as 
to be prepared for those who will inevitably be the next generation of library users.

Immigration to North Carolina is going to increase not decrease or even stay the same over the next decade. Research confirms that the longer immigrants are in the U.S., the better off they are. Exposure to good public schools and public libraries in North Carolina is essential for immigrants to improve their status. Possible solutions are not complicated, if there is the public will to provide services to immigrants where they live-in the languages they speak at work and at home-with welcoming librarians who are aware of cultural differences among immigrant groups.

\section{References}

${ }^{1}$ U.S. Department of Commerce, Bureau of the Census, Historical Statistics of the United States: Colonial Times to1970, Part 1, Bicentennial ed. (Washington, DC: GPO, 1975), 105-106; Michael Lemay, and Elliott Robert Barns, eds. U.S. Immigration and Naturalization Laws and Issues: A Documentary History, 41-42 (Westport, CT: Greenwood Press, 1999).

${ }^{2}$ Florence Anderson, Carnegie Corporation: Library Program, 1911-1961, 89 (New York: Carnegie Corporation, 1963).

${ }^{3}$ American Library Association (ALA), Library Journal 43 (2) (1918): 120.

${ }^{4}$ Horace M. Kallen, Culture and Democracy in the United States: Studies in the Group Psychology of the American Peoples (New York: Boni and Liveright, 1924; reprint, New York: Arno Press and the New York Times, 1970).

${ }^{5}$ John Foster Carr, Guide to the United States for the Immigrant Italian; A Nearly Literal Translation of the Italian Version, published under the auspices of the Connecticut Daughters of the American Revolution (Garden City, NY: Doubleday, Page, 1911).

${ }^{6}$ Margaret E. Monroe, Library Adult Education: The Biography of an Idea, 27 (New York: Scarecrow Press, 1963).

7 Wayne A. Wiegand, Irrepressible Reformer: A Biography of Melvil Dewey, 61-62 (Chicago: ALA, 1996)

8 "The ALA Committee on Work with the Foreign Born and the Movement to Americanize the Immigrant, in Libraries to the People: Histories of Outreach, 96-110, ed. by R. S. Freeman, \& D. M. Hovde, foreword by Kathleen de la Pena McCook (Jefferson, NC: McFarland, 2003).

9 Monroe, 27-28, 31-32; John Michael Handley, "The Carnegie Corporation and the American Association for Adult Education,” EdD diss. (Raleigh, NC: North Carolina State University, 1998).

${ }^{10}$ John Daniels, American Via the Neighborhood (New York: Harper Brothers, 1920); "Personnel of Americanization Survey," Library Journal 43 (July 1918): 505.

${ }^{11}$ William Learned, The American Public Library and the Diffusion of Knowledge (New York: Harcourt, Brace, 1924); Wiegand, 61-62.

${ }^{12}$ Judson T. Jennings, "Sticking to Our Last," ALA Bulletin 18 (Proceedings 1924): 150-56; Wiegand, 61-62.

${ }^{13}$ ALA Commission on the Library and Adult Education, Libraries and Adult Education (Chicago: ALA, 1926); Monroe, 32-34; John Cotton Dana, 1928, "To the Members of the Executive Board of the ALA," ALA Bulletin 22 (1) (1928): 9-12; Monroe, 30-32, 34-38; Anderson, 88.

${ }^{14}$ A Survey of Libraries in the United States, conducted by the American Library Association, 4 vols., Vol. 1: 7, 43, 44, 49, 50, 172, 177-78, 184, 187, 191, 198, 204, 206, 207, 211, 230, 232, 241, 249, 282-283, 287, 291 ; Vol. 2: 64, 158, 160, 161, 163, 164, 169, 175, 180, 181, 201, 208, 209, 218, 223, 267, 274, 293, 331, 233-64, passim, 346, 350; Vol. 3: 273; Vol. 4: 12, 14, 68, 74, 79, 95, 100, 116-17,124 (Chicago: ALA, 1926-27).

${ }^{15}$ Helen Lyman Smith, Adult Education Activities in Public Libraries; A Report of the ALA Survey of Adult Education Activities in Public Libraries and State Library Extension Agencies of the United States (Chicago: ALA, 1954); Smith; Eleanor Phinney, "ALA Projects: Supported by the Fund for Adult Education," ALA Bulletin 50 (9) (1956): 591-96.

${ }^{16}$ Ruth Warncke, The Library-Community Project of the American Library Association: Report 1955-1960 (Chicago: ALA, Prepared for the Fund for Adult Education, 1960); A Ten Year Report of the Fund for Adult Education, 1951 1961 [New York: Ford Foundation, 1962].

${ }^{17}$ Patrick M. Valentine, "International Developments: The North Carolina Foreign Language Center: A Public 
Library Service," Public Library Quarterly 5 (4) (1984): 47-61; Judi Lawson Wallace, "North Carolina’s Well-Kept Secret": The North Carolina Foreign Language Center. Foreign Language Annals 17 (1) (1984): 55-57.

${ }^{18}$ Natalia B. Bezugloff, "Library Services to Non-English-Language Ethnic Minorities in the United States," Library Trends 29 (2) (1980): 259-74.

${ }^{19}$ Kathleen Heim (now de la Pena McCook), and Danny P. Wallace, Adult Services: An Enduring Focus for Public Libraries, 1-26 (Chicago: ALA, 1990).

${ }^{20}$ Email correspondence, Oct. 24, 27, 2014, Jan. 2, 5, 2015P. A. Jones, Jr., with Jane Casto, Headquarter Services Manager, CCPL\&IC.

${ }^{21}$ Susan K. Burke, "Use of Public Libraries by Immigrants," RUSQ (Mar. 29, 2009), accessed, http://blog.rusq. org/2009/03/29/use-of-public-libraries-by-immigrants/; Rincon and Associates, Survey of Library Needs for North Carolina Hispanics (Raleigh, NC: State Library of North Carolina, 2000); Frances H. Flythe, "Identification of the Information Needs of Newly Arrived Hispanic/Latino Immigrants in Durham County, North Carolina, and How the Public Library May Address Those Needs," master's thesis, (Chapel Hill, NC: University of North Carolina, 2001); John Sudell, "Library Service to Hispanic Immigrants of Forsyth County, North Carolina: A Community Collaboration, in Library Services to Latinos: An Anthology, ed. Salvadore Guerena, 143-68 (Jefferson, NC: McFarland, 2000).

${ }^{22}$ Rebecca Tippett, (February 27, 2014), “Top 10 Non-English Languages Spoken in North Carolina in the period 2009 to 2011, accessed http://demography.cpc.unc.edu/2014/02/17; MPI (Migration Policy Institute), (2012), State demographics Data: North Carolina, accessed, http://www.migrationpolicy.org/data/state-profiles/state/demographics/NC.

${ }^{23}$ Steven A. Camarota, Immigrants in the United States: A Profile of America's Foreign-Born Population, 13-14, 38, 51, 66, 68, 74 (Washington, DC: Center for Immigration Studies, 2012).

\section{North Carolina Libraries}

Official Publication of the North Carolina Library Association

ISSN 0029-2540

The subscription cost to North Carolina Libraries is $\$ 50 / y r$.

All issues are available online free-of-charge at http://www.ncl.ecu.edu.

Back issues are available from the North Carolina Library Association office at 1811 Capital Blvd., Raleigh, NC 27604 , for $\$ 8$ an issue for those years prior to going online in 2002, or $\$ 50$ for the annual print compilation beginning with Vol. 60 (2002). 